\title{
Peningkatan Akuntabilitas Publik Melalui Sistem Informasi Akuntansi pada Pondok Pesantren Salafiyah
}

\author{
Dwi Sulistiani \\ UIN Maulana Malik Ibrahim Malang \\ dwisulistiani@pips.uin-malang.ac.id
}

\begin{abstract}
This study aims to determine the cash out transactions that occur in the Sabilurrosyad Islamic boarding school, analyze the internal control system, then compile the AIS cash outflow chart for the Sabilurrosyad boarding school so that it can increase public accountability. The research method is descriptive qualitative method using case studies. The results of the study indicate that internal control is still not good as evidenced by the existence of multiple tasks. Understanding of risk is still not understood by the leaders of Islamic boarding schools, information and communication is unclear. Monitoring has been carried out with the existence of monthly and annual financial reports, but it has not been compiled according to the accounting standards that should be. The flow chart has not been created so that the results of this study are in the form of a cash flow chart AIS can be used by the Sabilurrosyad boarding school.
\end{abstract}

Keywords: accounting information system, boarding school, accountability

\begin{abstract}
Abstrak
Penelitian ini bertujuan untuk mengetahui transaksi kas keluar yang terjadi di pondok pesantren Sabilurrosyad, menganalisis sistem pengendalian intern, kemudian menyusun flow chart SIA kas keluar untuk pondok pesantren Sabilurrosyad sehingga bisa meningkatkan akuntabilitas publik. Metode penelitian adalah metode kualitatif deskriptif dengan menggunakan studi kasus. Hasil penelitian menunjukkan bahwa pengendalian intern masih belum bagus terbukti dengan adanya perangkapan tugas. Pemahaman resiko masih belum dipahami oleh pimpinan pondok pesantren, informasi dan komunikasi belum jelas. Monitoring telah dilakukan dengan adanya laporan keuangan bulanan dan tahunan, tapi masih belum disusun sesuai dengan standar akuntansi yang seharusnya. Bagan alur dokumen (flow chart) belum dibuat sehingga hasil dari penelitian ini berupa flow chart SIA kas keluar bisa digunakan oleh pondok pesantren Sabilurrosyad.
\end{abstract}

Kata Kunci: sistem informasi akuntansi, pondok pesantren, akuntabilitas 


\section{PENDAHULUAN}

Pesantren merupakan lembaga pendidikan yang memiliki akar sosio-historis cukup kuat di masyarakat Indonesia. Hal ini menjadikan pesantren menduduki salah satu posisi relatif sentral pada dunia pendidikan di Indonesia untuk dapat bertahan pada berbagai gelombang perubahan. Pesantren harus memiliki kekuatan dan kemampuan strategis dalam menghasilkan manusia berkualitas, mendorong dan mengarahkan umat Islam meningkatkan aspek ekonominya demi mencapai kebahagiaan dunia dan akhirat (Rahim, 2013). Pondok pesantren merupakan salah satu organisasi sektor publik yang berarti dimiliki oleh masyarakat dan digunakan sepenuhnya untuk melayani masyarakat. Pondok pesantren salafiah merupakan jenis pondok pesantren klasik yang sudah sejak lama mewarnai kehidupan masyarakat Indonesia. Meskipun terkesan klasik tapi ilmu-ilmu yang diajarkan disana masih sangat dibutuhkan oleh santri-santri di Indonesia oleh karena itu masih banyak peminatnya.

Sangat menarik untuk memadukan keklasikan pondok pesantren salafiah dengan sistem akuntansi yang modern. Pondok pesantren perlu untuk meningkatkan akuntabilitasnya baik dari dana yang masuk maupun yang keluar. Pertanggungjawaban pada masyarakat sangat diperlukan untuk menjaga kepercayaan masyarakat terhadap pondok pesantren. Penelitian yang dilakukan oleh Salombe (2008), Larasati (2013), Harun (2013), Salupi dkk (2014), Nikmatuninayah (2014) dan Zamzami (2015) mengenai sistem informasi akuntansi (SIA) kas masuk dan keluar di yayasan menunjukkan bahwa sistem yang ada masih belum cukup efektif, terbukti dengan ada beberapa bagian dari sistem tersebut yang masih harus diperbaiki. Yayasan dan pondok pesantren juga masih belum menerapkan PSAK No. 45 dalam penyusunan laporan keuangannya. Masih belum efektifnya SIA di pondok pesantren salah satunya karena belum adanya aturan yang tegas bagi mereka untuk menyusun laporan keuangannya sesuai dengan standar akuntansi yang seharusnya.

Sejak buku pedoman pondok pesantren diterbitkan oleh Bank Indonesia (BI) dan Ikatan Akuntans Indonesia (IAI) serta mulai diberlakukan sejak Mei 2018, pondok pesantren harus mulai untuk meningkatkan akuntabilitas publiknya dengan menyusun laporan keuangannya sesuai dengan strandar akuntansi yang seharusnya. Berdasarkan fakta tersebut diatas penelitian ini ingin mengetahui sejauh mana penerapan akuntansi khususnya SIA kas keluar pada pondok pesantren setelah dikeluarkannya aturan dari BI bahwa pondok pesantren diwajibkan untuk menyusun laporan keuangan sesuai dengan standar akuntansi yang seharusnya.

Salah satu pesantren yang mengintegrasikan dimensi pendidikan agama dan dimensi pendidikan masyarakat adalah Pondok Pesantren Sabilurrosyad Kota Malang. Pesantren ini memiliki santri laki-laki dan perempuan yang sudah cukup banyak. Pondok pesantren ini telah melakukan pencatatan kas masuk dan keluar, tetapi masih belum sesuai dengan Standar Akuntansi yang seharusnya. Sistem informasi akuntansi (SIA) kas masuk dan keluar sudah ada tapi masih belum digambarkan dalam bagan alur diagram (flowchart), selain itu pengasuh pondok juga merasa sistem akuntansi yang ada masih perlu untuk diperbaiki. Penelitian ini tidak hanya menggambarkan SIA kas keluar di pondok pesantren 
salafiyah tapi juga memberikan solusi yaitu berupa rekomendasi berupa: rancangan formulir dan flow chart kas keluar yang diperlukan oleh pondok pesantren Sabilurrosyad Malang. Pandangan orang bahwa pondok pesantren salafiyah itu terkesan kuno dan tidak mengikuti perkembangan jaman itu salah. Dalam penelitian ini akan membuktikan bahwa pondok pesantren salafiyah pun mampu juga untuk menjalankan sisten informasi akuntansi yang sesuai sehingga akuntabilitas publiknya bisa meningkat.

Sistem informasi akuntansi merupakan seperangkat prosedur yang mempunyai tujuan menghasilkan informasi yang tepat dan berguna bagi semua pihak, informasi diperoleh dari pengumpulan dan pemrosesan data yang dapat digunakan sebagai bahan dalam pengambilan keputusan bagi pihak-pihak yang membutuhkannya. (Yusuf, 2009; Winarno, 2016). Teknik dalam sistem informasi akuntansi biasanya menggunakan Flowchart (bagan alur). Bagan alur (flowchart) inilah yang menunjukan arus data dan tahapan operasi dari satu bagian ke bagian lain yang terdiri dari beberapa prosedur dalam sebuah sistem.

Menurut Mulyadi (2010) unsur pengendalian intern dalam sistem akuntansi pengeluaran kas dengan cek dirancang dengan merinci unsur organisasi, sistem otorisasi, dan prosedur pencatatan, serta unsur praktek yang sehat, unsur organisasi yaitu: pertama, fungsi akuntansi harus terpisah dari fungsi penyimpanan kas. Kedua, bagian kasa tidak boleh melaksanakan sendiri transaksi kas masuk dan keluar tanpa campur tangan fungsi lain.

Pengendalian intern merupakan sebuah proses yang dipengaruhi oleh manajemen dan seluruh personil dalam suatu organisasi. Pengendalian intern didesain untuk menjamin tercapainya tujuan baik dalam operasional, pelaporan dan kepatuhan. Pengendalian internal hanya dapat menyediakan keyakinan memadai, bukan keinginan mutlak. Hal ini menegaskan bahwa sebaik apapun pengendalian internal itu dirancang dan dioperasikan, hanya dapat menyediakan keyakinan yang memadai, tidak dapat sepenuhnya efektif dalam mencapai tujuan pengendalian internal meskipun telah dirancang dan disusun sedemikian rupa dengan sebaik baiknya. Berhasil tidaknya sistem pengendalian intern bergantung pada kompetensi dan kendala dari pada pelaksanaannya dan tidak terlepas dari berbagai keterbatasan.

Terdapat beberapa komponen pengendalian intern yang harus ada dalam pengendalian intern suatu organisasi, yaitu: 1) Control environment atau lingkungan pengendalian. Merupakan tanggung jawab manajemen puncak untuk menyatakan dengan jelas nilainilai integritas dan kegiatan tidak etis yang tidak dapat ditoleransi. 2) Control activities atau kegiatan pengendalian. Untuk mengurangi terjadinya kecurangan, manajemen harus merancang kebijakan dan prosedur untuk mengidentifikasi resiko tertentu yang dihadapi perusahaan. 3) Risk assessment atau pemahaman risiko. Perusahaan harus mengidentifikasi dan menganalisis faktor-faktor yang menciptakan resiko bisnis dan harus menentukan bagaimana caranya mengelola resiko tersebut. 4) Information and communication atau informasi dan komunikasi. Sistem pengendalian internal harus dikomunikasikan dan diinfokan kepada seluruh karyawan perusahaan dari atas hingga bawah. 5) Monitoring atau pemantauan. Sistem pengendalian internal harus dipantau secara berkala. Apabila terjadi kekurangan yang signifikan, harus segera dilaporkan kepada manajemen puncak 
and ke dewan komisaris. Kelima komponen tersebut wajib ada dalam suatu organisasi dan dilakukan sesuai dengan kebutuhan untuk menghasilkan pengendalian intern yang baik.

Sistem informasi akuntansi harus berkembang sesuai kebutuhan informasi perusahaan dan perkembangan teknologi, untuk itu diperlukannya penyusunan kembali sistem akuntansi yang baru. Selanjutnya adalah desain/perancangan sistem. Terdapat tiga tahap dalam perancangan sistem akuntansi: pertama, melakukan evaluasi rancangan alternatif berdasarkan sistem yang diusulkan. Kedua, menyajian spesifikasi rancangan yang rinci. Ketiga, menyajikan laporan rancangan sistem.

Penelitian ini bertujuan untuk mengetahui transaksi kas keluar yang terjadi di pondok pesantren Sabilurrosyad. Selain itu, penelitian ini turut pula akan menganalisis sistem pengendalian intern, kemudian menyusun flow chart SIA kas keluar untuk pondok pesantren Sabilurrosyad sehingga bisa meningkatkan akuntabilitas publik.

\section{METODE}

Penelitian sistem akuntansi kas keluar ini menggunakan pendekatan kualitatif deskriptif. Lokasi penelitian adalah Pondok Pesantren Sabilurrosyad Gasek, Kota Malang, Jawa Timur. Data yang digunakan dalam penelitian ini meliputi data primer dan data sekunder yang diperlukan dalam menganalisis pengendalian intern, selanjutnnya membuat rancangan SIA kas keluar untuk pondok pesantren Sabilurrosyad.

Data Primer, berupa observasi, wawancara dan focus group discussion (FGD). Observasi dilakukan dengan cara melihat secara langsung sistem akuntansi penerimaan dan pengeluaran kas di Pondok Pesentren Sabilurrosyad. Prosedur apa saja yang dilalui yang membentuk sistem akuntansi pengeluaran kas. Wawancara dilakukan dengan cara memberikan pertanyaan secara lisan kepada pihak-pihak yang terkait dengan system informasi akuntansi kas masuk dan kas keluar. Wawancara dilakukan dengan ketua yayasan/ pondok pesantren, bagian keuangan, bendahara/ kasir, bagian akuntansi dan pihak-pihak lain yang terkait. Hasil waancara tersebut kemudian dicatat secara lengkap untuk mendapatkan informasi baik tertulis ataupun lisan terkait prosedur dan arus formulir di Pondok Pesantren Sabilurrosyad.

Data Sekunder, berupa kepustakaan dan dokumentasi. Terdiri dari buku-buku literatur, jurnal-jurnal penelitian yang terkait dengan sistem akuntansi pengeluaran kas, dan lain sebagainya. Dokumentasi digunakan untuk memperoleh data berupa struktur organisasi, formulir, faktur, kebijakan-kebijakan tertulis dan dokumen-dokumen lainnya yang ada di lapangan.

Metode triangulasi dilakukan dalam penelitian ini guna memeriksa keabsahan data yang didapat oleh peneliti selama pengambilan data berlangsung dengan memanfaatkan suatu data lain untuk dikonfirmasi kebenarannya (Moleong, 2010) Dalam menganalisis data dan menjawab masalah penelitian dilakukan langkah-langkah sebagai berikut: Pertama, survey Pendahuluan. Dilakukan terlebih dahulu dengan melakukan kunjungan ke Pondok Pesantren Sabilurrosyad. Kedua, Mendata semua transaksi yang terjadi di pondok pesantren terkati dengan kas masuk dan kas keluar. Ketiga, analisis. Pada tahap ini penggunaan literatur sangat dibutuhkan untuk mengetahui bagaimanakah sistem informasi akuntansi kas keluar 
yang efektif kemudian digabungkan hasil penelitian di lapangan akan bisa menghasilkan rancangan kas keluar yang sesuai untuk pondok pesantren Sabilurrosyad. Berdasarkan hasil perbandingan tersebut kekurangan atau kelemahan dari sistem akan dapat dibuat rekomendasi untuk memperbaiki sistem yang sudah ada sebelumnya. Keempat, Perancangan. Tahap perancangan digunakan untuk membuat rancangan formulir dan menyusun flow chart (bagan alur dokumen) terkait SIA kas keluar baik secara naratif ataupun dalam bentuk gambar flow chart. Kelima, kesimpulan dan rekomendasi berupa rancangan sistem informasi akuntansi kas keluar yang efektif. Tahap ini dihasilkan berdasar penjabaran data penelitian beserta analisis sesuai dengan teori-teori dan literatur yang ada.

\section{HASIL DAN PEMBAHASAN}

Pondok Pesantren Sabilurrosyad memiliki beberapa departemen yang berada dalam satu Yayasan Sabilurrosyad, yaitu: SMPI Sabilurrosyad, SMAI Sabilurrosyad, Madrasah Diniiyah, TPQ, BLK (Balai Latihan Kerja) dan Pondok Pesantren Putra. Penelitian untuk memilih SMPI Sabilurrosyad untuk menjadi contoh salah satu departemen di pondok pesantren Sabilurrosyad. Departemen ini menghasilkan surplus dalam pendanaannya sehingga bisa digunakan untuk membiayai departemen yang lain.

Transaksi kas keluar dilakukan dengan menggunakan mekanisme anggaran yang sudah setujui oleh kepala sekolah dan pengurus yayasan untuk tahun berikutnya. Anggaran disusun oleh tim manajemen sekolah yang terdiri dari : kepala sekolah, wakil kepala sekolah, guru, pengurus komite sekolah dan bendahara sekolah. Anggaran disusun dengan menggunakan dokumen Rencana Kerja Anggaran Sekolah (RKAS). Dalam anggaran tersebut selain memuat anggaran pendapatan juga memuat anggaran belanja sekolah serta dana cadangan yang digunakan untuk pengeluaran yang tidak terduga. Laporan keuangan dilaporkan tiap bulan untuk manajemen sekolah dan tiap tahun untuk yayasan. Laporan keuangan terkait dengan BOS dan BOSDa sudah menggunakan prosedur dan bentuk laporan yang jelas berdasarkan aturan pemerintah terkait mekanisme pengajuan dan pelaporan dana BOS dan BOSDa untuk sekolah yang sudah memenuhi syarat.

Transaksi kas keluar terdiri dari: Belanja gaji, Belanja ATK, Belanja bahan (selain ATK), Belanja pemeliharaan, Belanja modal yang terdiri dari: Tanah, Gedung, Peralatan, Belanja perjanan/transportasi, Belanja konsumsi, Belanja listrik dan air, Belanja tendik (tenaga pendidik) dan Belanja lain-lain

Dana pondok pesantren diperoleh dari dana pemerintah dan dana bukan dari Pemerintah. Dana bukan dari pemerintah digunakan untuk pembelian, sewa dan untuk gaji karyawan. Kas bisa dikeluarkan untuk semua pembelian dan sewa yang sudah direncanakan sebelumnya dengan mengajukan proposal dan disetujui oleh ketua yayasan dan kepala sekolah. Bendahara menyimpan data proposal untuk kemudian membayarnya saat akan dilakukan pembelian atau sewa. Setelah selesai kegiatan, penanggungjawab kegiatan harus membuat laporan kegiatan untuk kemudian disimpan sebagai bukti oleh bendahara. Penggajian dilakukan untuk karyawan saja, sedangkan pengurus yayasan tidak memperoleh gaji. Besaran gaji ditentukan oleh lembaga tersebut sesuai dengan UMR. 
Pengeluaran kas yang berasal dari dana BOS (dana pemerintah) hanya bisa digunakan untuk pengeluaran operasional yang sifatnya rutin sepert: perlengkapan, honorarium, pemeliharaan gedung, alat peraga, percetakan, fotocopy, konsumsi, dan pemeliharaan prasarana lainnya. Prosedur pembelian dan pengeluaran kas: Alat Tulis, alat peraga, percetakan, foto copy, konsumsi, pemeliharaan gedung dan prasarana lainnya. 1) Bagian TU mengecek kartu stok barang dan mengajukan pembelian saat persediaan sudah menipis. 2) Membuat daftar permintaan barang. 3) Menyerahkannya kepada bendahara.

Honorarium: 1) Pembayaran honorarium guru yang menjabat dan guru ekstra kulikuler didasarkan pada SK yang telah dikeluarkan oleh ketua yayasan dan kepala sekolah. 2) Waka Kurikulum membuat rencana anggaran terkait honorarium. 3) Waka kurikulum membuat rekap anggaran dan pengeluaran kas untuk honorarium berdasarkan SK yang telah ada.

Prosedur Pembuatan Bukti Kas Keluar: 1) Kepala TU melakukan verifikasi terhadap BAP dan surat pesanan barang. 2) Melakukan pencocokan data faktur dengan BAP. 3) Jika sesuai kemudian membuat tanda terima faktur. 4) Menyerahkannya pada supplier. 5) Melakukan verifikasi terhadap bukti (menghitung ulang). 6) Mencatat dalam bukti kas keluar (BKK) sesuai besarnya tagihan. 7) Melakukan paraf pada BKK. 8) Membuat buku control anggaran unit dan mencatat BKK tersebut di buku itu. 9) Mengajukannya pada bagian bendahara, minta persetujuan kepala sekolah untuk bisa dikeluarkan uangnya. 10) Melakukan pembayaran oleh bendahara.

Pihak-pihak yang terlibat terkait pengendalian Internal menurut COSO (The Committee of Sponsoring Organizations) adalah dewan komisaris, manajemen, dan pihak-pihak lainnya yang mendukung pencapaian tujuan organisasi. Selain itu juga bahwa tanggung jawab untuk penetapan, penjagaan, dan pengawasan sistem Pengendalian Internal adalah tanggung jawab manajemen. Di pondok pesantren yang merupakan organisasi nirlaba, peran dewan komisaris digantikan oleh masyarakat, sedangkan manajemen dilakukan oleh pengurus pondok pesantren dan pengelolan sekolah yang berada di bawah yayasan pondok pesantren tersebut.

Berdasarkan wawancara dan observasi yang dilakukan di pondok pesantren Sabilurrosyad khususnya di SMPI Sabilurrosyad dapat dipaparkan bahwa lingkungan pengendalian masih belum begitu bagus. Hal tersebut terbukti dengan adanya perangkapan tugas antara bagian kasir dan bagian accounting, kemudian perangkapan tugas bagian gudang dan bagian pembelian yang dilakukan oleh bagian pengadaan barang (Hasil wawancara dengan bendahara SMPI Sabilurrosyad).

Kegiatan pengendalian yang dilakukan adalah adanya approve/persetujuan dari pihak kepala sekolah untuk pengeluaran yang sifatnya tidak rutin, untuk pengeluaran rutin tidak perlu diapprove. Mengenai pemahaman resiko juga masih belum dipahami oleh pihak pengelola pondok pesantren. Berdasarkan wawancara dengan wakil kepala sekolah bidang kurikulum dapat dipaparkan bahwa mereka belum paham terkait resiko keuangan yang dihadapi baik itu kecurangan maupun kehilangan. Sistem di pondok pesantren masih mengandalkan kepercayaan yang tinggi kepada karyawannya yang itu memang menjadi ciri khas akuntansi di pondok pesantren. 
Informasi dan komunikasi juga masih belum jelas, terbukti dengan bentuk laporan keuangan yang masih belum tau bagaimana menyusunnya, sehingga pengelola tidak tau bagaimana kinerja mereka dari tahun ke tahun terkait keuangan. Laporan keuangan yang kurang informatif tersebut sebenarnya akan dapat mengurangi nilai mereka saat ada akreditasi sekolah melakukan visitasi. Jenjang komunikasi sudah mulai terstruktur tapi ada kalanya komunikasi tersebut dipotong garis komunikasinya saat ada keperluan yang mendesak, apalagi saat pemilik pesantren yang menyuruhnya. Dalam garis komunikasi di pondok pesantren peran kyai menjadi sangat penting dan semua perkataannya adalah perintah yang harus dilakukan oleh santri dan pegawainya. Kharisma Kyai sebagai orang yang dapat dipercaya dan mempunyai pengetahuan yang tinggi menjadi pusat komunikasi di pondok pesantren.

Monitoring dilakukan oleh SMPI Sabilurrosyad dilakukan dengan adanya laporan keuangan bulanan yang diberikan bendahara pada kepala sekolah dan laporan keuangan tahunan yang diserahkan kepada pengurus pondok pesantren. Hanya saja setelah dilakukan pelaporan keuangan, hasil nya tidak digunakan untuk tindakan perbaikan atau mengukur kinerja organisasi agar bisa mencapai tujuan dan menjadi lebih baik lagi.

Masalah yang dihadapi di SMPI Sabilurrosyad adalah masih belum bisa menyusun laporan yang sesuai dengan standar akuntansi keuangan yang berlaku untuk menyusun laporan keuangan di pondok pesantren yang dananya berasal dari dana sendiri (bukan dari bantuan pemerintah). Kendalanya adalah bahwa bendahara bukan memiliki kompetensi di bidang keuangan ataupun akuntansi sehingga belum begitu paham terkait penyusunan laporan keuangan serta mekanisme atau sistem yang seharusnya dilakukan. Berdasarkan permasalahan dan kendala tersebut diperlukan sebuah rancangan sistem akuntansi khusunya kas masuk dan kas keluar yang bisa membantu menjadi acuan dalam transaksi kas masuk dan kas keluar di SMP ini.

Berdasarkan transaksi yang terjadi dapat dianalisi bahwa transaksi kas masuk dan kas keluar di SMPI Sabilurrosyad dilakukan oleh satu orang bendahara baik itu kas masuk maupun untuk kas keluar. Pencatatan dan penyusunan laporan keuangan juga dilakukan oleh bendahara tersebut, hal ini melanggar teori tentang pengandalian intern bahwa personil untuk kasir/bendahara tidak boleh merangkap sebagai pencatat/bagian akuntansi. Namun hal ini dalam kenyataannya tidak menimbulkan masalah baik pencurian atau kecurangan dikarenakan kepercayaan yang dibangun di pondok pesantren Sabilurrosyad sangat kuat sehingga semua pegawai menjaga amanah yang telah diberikan oleh kyai mereka. Hal inilah yang berbeda antara pengendalian intern di perusahaan dengan di pondok pesantren karena peran kyai sebagai pemimpin yang kharismatik sangatlah besar sehingga pegawainya selalu menjaga amanah meskipun tidak diawasi. Dilingkungan pondok pesantren dengan spiritualisme yang sangat tinggi merupakan pengendalian intern tersendiri, karena mereka takut pada Allah yang selalu mengawasi mereka.

Dalam standar akuntansi (SAK ETAP) mewajibkan untuk setiap entitas untuk melakukan pencatatan dengan system double entry. Sistem tersebut mengharuskan pencatatan atau jurnal dilakukan pada tiap transaksi dengan melakukan debit dan kredit pada rekening 
yang bersangkutan. Satu transaksi harus melibatkan setidaknya satu rekening yang di debet dan satu rekening yang di kredit, sehingga terjadi keseimbangan antara debit dan kreditnya. Tabel 1 memperlihatkan contoh perbedaan sistem single entry dan double entry.

Tabel 1. Sistem pencatatan single entry dan double entry

\begin{tabular}{lllll}
\hline \multicolumn{2}{c}{ Pencatatan Single Entry } & \multicolumn{3}{c}{ Pencatatan Double Entry } \\
\hline Pendapatan-SPP & Rp xxx & Kas & Rp xxx & Rp xxx \\
& & Pendapatan-SPP & Rp xxx \\
Perlengkapan & Rp xxx & Perlengkapan & Rp xxx \\
& & Kas & & \\
\end{tabular}

Sumber: Data Diolah 2018

Aset bertambah di sisi debit, pendapatan bertambah di sisi kredit, beban bertambah di sisi debit, sedangkan kewajiban dan aset neto bertambah di sisi kredit. Buku besar merupakan tahap selanjutnya setelah dilakukan jurnal, maka harus diposting ke buku besar tiap rekening yang ada sesuai dengan kode rekening diatas. Tahap terakhir adalah penyusunan laporan keuangan yang sesuai untuk pondok pesantren, yang terdiri dari: Laporan posisi keuangan, Laporan aktivitas, Laporan arus kas dan catatan atas laporan keuangan sesuai dengan PSAK No. 45. Tabel 2 menunjukkan rancangan catatan untuk Yayasan Pondok Pesantren Sabilurrosyad.

Tabel 2. Rancangan Buku Kas

\begin{tabular}{lllll}
\hline Tanggal & Keterangan & Debit & Kredit & Saldo \\
\hline
\end{tabular}

Dokumen yang digunakan oleh pondok pesantren Sabilurrosyad adalah dokumen transaksi (bukti kas keluar, nota, kwitansi, faktur, dll) serta dokumen buku catatan transaksi berupa buku jurnal dan buku besar. Tabel 3 merupakan rancangan dokumen yang bisa digunakan oleh Pondok Pesantren Sabilurrosyad.

Tabel 3. Rancangan Buku Jurnal

\begin{tabular}{llll}
\hline Tanggal & Keterangan & Debit & Kredit \\
\hline
\end{tabular}

Analisis pada catatan pertama untuk kas masuk dilakukan pada buku pembantu SPP yang dibuat oleh bendahara dimana buku pembantu tersebut membantu sekolah untuk mengetahui siapa santri yang sudah bayar SPP ataupun yang belum. Meskipun bentuk buku pembantu masih belum sesuai tapi cukup untuk memberikan informasi yang 
dibutuhkan. Analisis pada catatan terakhir di SMPI Sabilurrosyad masih belum menyusun laporan keuangan, hal tersebut dikarenakan bendahara masih belum tau bagaimana bentuk laporan keuangan yang seharusnya. Oleh karena itu sangat diperlukan perancangan kode akun, formulir yang dibutuhkan, catatan yang harus dilakukan, bentuk laporan keuangan dan bagan alur dokumen (flowchart) terkait kas keluar yang dilakukan di SMPI ini. Tiap bukti transaksi yang terjadi baik itu kas masuk maupun kas keluar harus dicatat dalam buku jurnal yang terdiri dari tanggal, keterangan dan debit serta kredit yang menunjukkan posisi dalam logika akuntansi, hal ini sebagaimana terlihat pada Tabel 4.

Tabel 4. Rancangan Buku Besar

Nama Akun..... Kode Akun.......

\begin{tabular}{lllll}
\hline Tanggal & Keterangan & Debit & Kredit & Saldo \\
\hline
\end{tabular}

Formulir kas keluar digunakan sebagai bukti intern terkait transaksi kas keluar dengan nomor urut tercetak yang nantinya akan dilampiri oleh bukti ekstern berupa nota, kwitansi, dll untuk kas keluar. Tabel 5 merupakan rancangan formulir kas keluar.

Tabel 5. Rancangan Formulir Kas Keluar

\begin{tabular}{|c|c|c|}
\hline $\begin{array}{l}\text { SMPI Sabilurrosyad } \\
\text { Jl. Candi VI C No. } 303 \text { Karangbesuki Sukun Malang }\end{array}$ & $\begin{array}{l}\text { Bukti Kas Keluar } \\
\text { No. KK00000001 }\end{array}$ & \\
\hline \multicolumn{3}{|l|}{ Surat Perintah Membayar } \\
\hline Uraian & & Jumlah \\
\hline \multicolumn{3}{|l|}{ TOTAL } \\
\hline \multicolumn{3}{|l|}{ Terbilang : } \\
\hline \multicolumn{3}{|l|}{ Keterangan: } \\
\hline Disetujui & Menyetujui & $\begin{array}{l}\text { Malang, } \\
\text { Yang Menerima }\end{array}$ \\
\hline
\end{tabular}

Berdasarkan analisis yang dilakukan berikut ini rekomendasi rancangan SIA kas keluar untuk pondok pesantren Sabilurrosyad: Kas keluar untuk Pembelian atau Sewa. (a) Panitia Kegiatan. 1) Menyusun proposal kegiatan dan anggaran biaya. 2) Mengajukan permohonan pembelian atau sewa pada ketua yayasan. 3) Menyerahkan permohonan tersebut pada bendahara setelah mendapat persetujuan dari ketua yayasan. 4) Menerima uang dan bukti kwitansi pembelian atau sewa. 5) Menyusun pertanggungjawaban atas uang yang diterima. 6) Meyerahkan lembar pertanggungjawaban pada akunting. (b) Akunting. 1) Menerima kwitansi lembar 2 sebagai bukti kas keluar. 2) Melakukan pencatatan transaksi pada buku jurnal. 3) Melakukan posting ke buku besar. 4) Menerima laporan pertanggungjawaban 
(LPJ) dan memeriksa kebenarannya.

Arsip LPJ. (a) Ketua yayasan. 1) Menerima proposal dari panitia kegiatan beserta RAB nya. 2) Mengecek proposal dan RAB. 3) Memberikan keputusan untuk menyetujui atau tidak proposal tersebut. 4) Menandatangani proposal jika menyetujuinya. (b) Bendahara yayasan. 1) Menerima proposal dan RAB yang telah disetujui oleh ketua yayasan. 2) Melakukan cek atas kebenaran proposal dan RAB. 3) Membuat kwitansi rangkap tiga untuk: panitia kegiatan, akuntan dan arsip. 4) Menyerahkan uang pada panitia kegiatan sesuai dengan proposal yang disetujui. 5) Menyerahkan kuitansi lembar 2 pada akunting untuk dicatat dalam jurnal.

Sistem kas keluar untuk penggajian: (a) Tata Usaha. 1) Melakukan cek daftar absen karyawan. 2) Menyusun daftar potongan baik yang rutin maupun tidak rutin. 3) Mengecek data perubahan gaji untuk disesuaikan. 4) Mencetak daftar gaji. 5) Mengajukan daftar gaji pada kepala sekolah untuk dicek dan disetujui. (b) Kepala sekolah: menerima daftar gaji, mengecek dan menyetujuinya. (c) Ketua yayasan. 1) Menerima surat pembayaran dan daftar gaji untuk disetujui. 2) Membuat surat kuasa pencairan dana untuk diberikan pada bendahara. (d) Akunting. 1) Menerima bukti pembayaran gaji dari bendahara. 2) Melakukan pencatatan dalam buku jurnal. 3) Melakukan posting ke buku besar. (e) Bendahara Yayasan. 1) Menerima surat kuasa pencairan dana dan bukti pembayaran gaji. 2) Menandatangani surat kuasa pencairan dana. 3) Membayar gaji secara tunai ataupun auto debet bank. 4) Menyerahkan bukti pembayaran pada bagian akunting untuk dicatat.

\section{SIMPULAN}

Berdasarkan analisis transaksi dengan model COSO menemukan bahwa lingkungan pengendalian masih belum begitu bagus. Hal tersebut terbukti dengan adanya perangkapan tugas antara bagian kasir dan bagian accounting. Kemudian perangkapan tugas bagian gudang dan bagian pembelian yang dilakukan oleh bagian pengadaan barang. Kegiatan pengendalian perlu ditingkatkan dengan adanya persetujuan dari pihak kepala sekolah untuk pengeluaran yang sifatnya tidak rutin. Mengenai pemahaman resiko juga masih belum dipahami oleh pihak pengelola pondok pesantren. Pihak pengelola pondok pesantren Sabilurrosyad belum paham terkait resiko keuangan yang dihadapi baik itu kecurangan maupun kehilangan. Sistem di pondok pesantren masih mengandalkan kepercayaan yang tinggi kepada karyawannya yang itu memang menjadi ciri khas akuntansi di pondok pesantren. Monitoring dilakukan dengan adanya laporan keuangan bulanan yang diberikan bendahara pada kepala sekolah dan laporan keuangan tahunan yang diserahkan kepada pengurus pondok pesantren. Perancangan SIA kas keluar berupa catatan, formulir dan flowchart telah memperhatikan sistem pengendalian internal yang dibutuhkan oleh pondok pesantren Sabilurrosyad. Perancangan flowchart terdiri dari: flowchart prosedur aktivitas pembiayaan dan aktivitas pembiayaan gaji.

Berdasarkan kesimpulan diatas dapat direkomendasikan sebagai berikut: Pertama, transaksi-transaksi yang terjadi bisa lebih diperjelas dan dicatat secara tertib dalam formulir serta catatan yang ada. Kedua, adanya pemisahan tugas antara bagian kasir dan 
bagian accounting serta bagian pembelian dan bagian gudang, struktur organisasi juga disesuaikan dengan kebutuhan. Ketiga, Perancangan SIA kas keluar memang diperlukan oleh pondok pesantren Sabilurrosyad untuk bisa lebih menertibkan administrasi keuangan disana. Perancangan bagan alur dokumen (flowchart) yang sudah dibuat bisa digunakan dalam kegiatan keuangan yang ada.

\section{PUSTAKA ACUAN}

Harun, L. (2013). Sistem Informasi Akademik Berbasis Web Pada Pondok Pesantren Roudlotussholihin Purosari Lampung. Proceeding Konferensi Mahasiswa Sistem Informasi..

Larasati, I. (2013). Analisis Sistem Informasi Akuntansi Pencatatan dan Pengelolaan Keuangan Pada Yayasan Muqimus Sunnah. Skripsi Tidak Dipublikasikan. Yogyakarta: STIE MDP.

Moleong, L. J. (2017). Metodologi Penelitian Kualitatif. Bandung: Penerbit PT Remaja Rosdakarya Offset.

Mulyadi. (2010). Sistem Akuntansi. Jakarta: Penerbit Salemba Empat.

Nikmatuniayah. (2014). Penerapan Teknologi Laporan Kuangan berdasarkan SAK ETAP dan PSAK 45 IAI pada Yayasan Daruttaqwa Kota Semarang. Prosiding SNA PP: Sosial. Ekonomi. dan Humaniora.

Rahim, H. (2013). Pola Pemberdayaan Masyarakat Melalui Pesantren. Jakarta: Ditpekapontren Ditjen Kelembagaan Agama Departemen Agama RI.

Salombe, D. M. (2008). Analisis Prosedur Penerimaan dan Pengeluaran Kas pada Sinode Gereja Masehi Injili Sangihe Talaud (GMIST) di Kabupaten Sangihe. Skripsi Tidak Dipublikasikan. Manado: Univeristas Samratulangi.

Salupi, R., Halim, A., \& Fauzan. (2014). Evaluasi Sistem Pengendalian Intern atas Pengeluaran Kas pada Yayasan Pendidikan Islam dan Sosial Al Kautsar Assofyaniyah Blitar. Jurnal Riset Mahasiswa Akuntansi, 2(1), 1-10.

Winarno, W. W. (2016). Sistem Informasi Akuntansi. Yogyakarta: UPP STIM YKPN

Yusuf, H. (2009). Dasar-Dasar Akuntansi. Yogyakarta: STIE KPN.

Zamzami, N. (2015). Perancangan Sistem Informasi Akuntansi pada Yayasan Al-Inayah Purwosari Pasuruan. Skripsi Tidak Dipublikasikan. Malang: UIN Maulana Malik Ibrahim. 